\title{
A PRELIMINARY STUDY OF THE DISTRIBUTION AND MOBILITY OF MERCURY IN WATER AND SEDIMENTS FROM THE SAN JUAN RIVER WATERSHED, NUEVO LEON MEXICO
}

\author{
ROBERTO MACÍAS MEDRANO', JUAN MANUEL ALFARO BARBOSA ${ }^{1 \cdots}$, LAURA HINOJOSA REYES ${ }^{l}$, \\ ARACELY HERNÁNDEZ-RAMÍREZ ${ }^{1}$, KARIM ACUÑA-ASKAR ${ }^{2}$
}

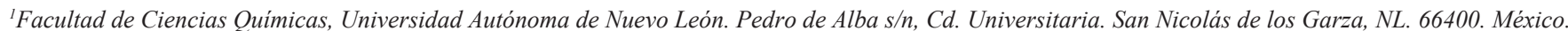
${ }^{2}$ Facultad de Medicina, Universidad Autónoma de Nuevo León. Av. Madero y Dr. Aguirre s/n, Col. Mitras Centro, Monterrey, NL. 64460. México. 'Corresponding author: Juan Manuel Alfaro Barbosa. Tel: +52 (8220-4900), ext. 3461. Fax: +52 (8376-8553)
\end{abstract}

(Received: August 17, 2010 - Accepted: December 2, 2010)

\begin{abstract}
Monitoring of distribution and fractionation of mercury ( $\mathrm{Hg}$ ) from within the San Juan River Basin that provides water for the Metropolitan Area of Monterrey, Mexico (MAM), was performed. The purpose of this work was to characterize the risk of $\mathrm{Hg}$ exposure to human populations that reside in communities nearby the area. Total $\mathrm{Hg}$ was quantified from water and surface sediments $(0-10 \mathrm{~cm})$ collected from 11 locations during the summer season of 2006 . The analysis of $\mathrm{Hg}$ was carried out by Cold Vapor Atomic Absorption Spectroscopy (CVAAS). Simultaneously, some relevant physical and chemical parameters were analyzed in water samples and correlated to $\mathrm{Hg}$ concentrations to trace the fate of $\mathrm{Hg}$ in the watershed. In the river water samples, $\mathrm{Hg}$ levels were in the range from 0.17 to 1.14 $\mu \mathrm{g} / \mathrm{L}$. The mean concentration level of $\mathrm{Hg}$ in sediment samples was $0.405 \pm 0.074 \mathrm{mg} / \mathrm{Kg}$ and showed a uniform Hg distribution along the San Juan River Basin, conversely, the fractionation studies showed that chemical speciation plays an important role in stability and low mobility.
\end{abstract}

Keywords: mercury; fractionation; sediments; waterbodies; San Juan River watershed; Monterrey, Mexico.

\section{INTRODUCTION}

According to the United States Environmental Protection Agency (US EPA), mercury ( $\mathrm{Hg}$ ) is a priority contaminant of continuous concern on the global scale [1]. Numerous national and international agencies and organizations have targeted $\mathrm{Hg}$ for emission control due to its persistence, bioaccumulation and toxicity in the environment [2]. Although aquatic $\mathrm{Hg}$ contamination is a result of atmospheric deposition and terrestrial sources from natural and anthropogenic origin [3], regional emission sources could significantly contribute to $\mathrm{Hg}$ loadings through discharges from industrial processes, mining activities, and watershed runoff $[4,5]$. In the environment, elemental and inorganic $\mathrm{Hg}$ is deposited on aquatic sediments where a fraction reacts with sulfate to form mercury sulfide, which is not soluble, and therefore, its bioavailability becomes significantly reduced, whereas a small percentage is converted to methylmercury $(\mathrm{MeHg}$ ) by bacteria. $\mathrm{MeHg}$ is an environmental neurotoxicant which is bioaccumulated and biomagnified in the food web [2]. Therefore, information regarding concentrations and transport of $\mathrm{Hg}$ in aquatic ecosystems is needed to predict potential impact on both human and aquatic life.

Worldwide contamination of $\mathrm{Hg}$ has been reported in aquatic systems [6-11], including contamination in Mexico [12-14]. However, no data has been published concerning the distribution of $\mathrm{Hg}$ contamination in the San Juan River watershed ecosystem. The San Juan River watershed is located in northeastern Mexico and belongs to the Bravo-Conchos River basin. The San Juan River basin has a total surface area of approximately $33000 \mathrm{Km}^{2}$ comprising the states of Coahuila (40\%), Nuevo Leon (57\%), and Tamaulipas (3\%). The watershed includes a number of smaller tributary basins such as Pesqueria River, Santa Catarina River, San Juan River, and Pilon River. Among the various rivers that make up this basin, the San Juan River is the largest and most important river in the Mexican state of Nuevo Leon and stands out as the major tributary of the lower Grande/Bravo River basin. This river originates in the mountain range of the Sierra Madre Oriental Mountain, approximately $30 \mathrm{Km}$ southeast Monterrey and runs across the border between Mexico and USA from Ciudad Juarez (Chihuahua) and El Paso (Texas) to its outlet into the Gulf of Mexico near Matamoros (Tamaulipas) and Brownsville (Texas). The San Juan River supplies the Cuchillo reservoir, which provides water for the Metropolitan Area of Monterrey (MAM) [15-17]. The MAM is the third largest metropolitan area in Mexico and holds a population of approximately four million inhabitants [18]. Although a number of water quality studies have been conducted within the San Juan River watershed, serious problems associated to the persistence of heavy metal pollution have been reported $[19,20]$. A study conducted in the Santa Catarina River tributary of the San Juan River reported contamination by $\mathrm{Fe}, \mathrm{Cu}, \mathrm{Zn}, \mathrm{Cd}$, and $\mathrm{Sr}$ in sediments [17]. Subsequently, Flores-Laureano and Navar [20] assessed the pollution of the
San Juan River and its tributary Santa Catarina River during the period 19951996. Metals including Al, As, Ba, Cd, Cu, Cr, Fe, Mn, Pb and Fe, exceeded the drinking water quality standards set by the Mexican environmental regulations. Furthermore, this study reported bacteriological and physical parameters that exceeded the drinking water quality standards. Thus, the need for monitoring other relevant priority pollutants such as $\mathrm{Hg}$ is mandatory for improving our understanding and assessment of this complex water ecosystem.

The aim of this work was to investigate $\mathrm{Hg}$ concentrations in surface water and sediments in the San Juan River watershed and evaluate changes in $\mathrm{Hg}$ distribution along different sampling sites followed by an assessment of the degree of environmental impact and human exposure to $\mathrm{Hg}$. In addition, a three-step sequential extraction procedure (SEP) described in the United States Environmental Protection Agency (US EPA) method 3200 [21] was applied to evaluate $\mathrm{Hg}$ fractionation and mobility in the sediment samples.

\section{EXPERIMENTAL}

\subsection{Study area and sampling}

Water and sediment samples were collected in 11 locations from the San Juan River watershed situated in the state of Nuevo Leon in August 2006 (Fig. 1). Shallow water samples were taken nearby the river bank. Surface sediment samples in the depth range $0-10 \mathrm{~cm}$ were collected. Six sites were selected along the Santa Catarina River from the eastern suburbs of the city of Monterrey to its junction with the River San Juan; one sample was collected from the La Silla River, at the intersection of this river course and Santa Catarina tributary; three additional sites were located along the San Juan River, between the Boca and the Cuchillo reservoirs; and one sample was collected from the Cuchillo reservoir in the municipality of China, Nuevo Leon, located at $102 \mathrm{Km}$ eastern Monterrey.

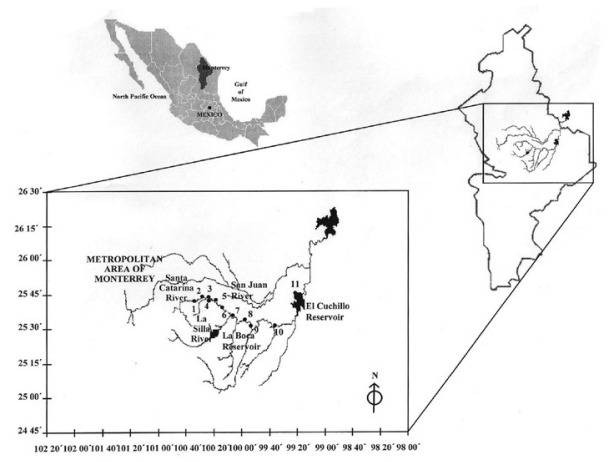

Fig. 1. The San Juan watershed and sampling point locations. 
Fifty seven percent of the San Juan River watershed has a tropical weather, whereas thirty four percent ranges from semiarid to arid. Monthly rainfall has a bimodal type of distribution, with the first peak occurring in May-June and the second peak, the most important in terms of total depth, occurring during September-October. The annual average rainfall varies from $200 \mathrm{~mm}$ to $1500 \mathrm{~mm}$ [15]. Metropolitan Area of Monterrey soils are characterized by Feozem, Cambisol and Regosol soils with calcareous structures [22].

2.1.1 Water samples. Water samples were collected at the surface $(0.5 \mathrm{~m}$ depth) in $500 \mathrm{~mL}$ cleaned polytetrafluoroethylene (PTFE) bottles. Characterizations and localization of observed water ecosystems are presented in Table 1.

Table 1. Localization and characteristics of observed water ecosystems.

\begin{tabular}{|c|c|c|c|c|c|c|c|c|c|c|}
\hline Sample & Site & $\begin{array}{l}\text { Latitude } \\
(N)\end{array}$ & $\begin{array}{l}\text { Longitude } \\
(W)\end{array}$ & $\begin{array}{c}\text { Total } \mathrm{Hg} \\
(\mu \mathrm{g} / L)\end{array}$ & $\begin{array}{c}\text { Temperature } \\
\left({ }^{\circ} \mathrm{C}\right)\end{array}$ & $p H$ & $\begin{array}{c}T D S \\
(m g / L)\end{array}$ & $\begin{array}{c}\text { Conductivity } \\
(\mu S / \mathrm{cm})\end{array}$ & $\begin{array}{c}E_{h} \\
(m V)\end{array}$ & $\begin{array}{c}\text { Salinity } \\
(\mathrm{mg} / \mathrm{L})\end{array}$ \\
\hline 2 & $\begin{array}{c}\text { Santa } \\
\text { Catarina } \\
\text { River }\end{array}$ & $25^{\circ} 41^{\prime} 27^{\prime \prime}$ & $100^{\circ} 09^{\prime} 51^{\prime \prime}$ & $0.85 \pm 0.02$ & 31.8 & 8.35 & 252 & 514 & 94.2 & 0.1 \\
\hline 4 & $\begin{array}{l}\text { La Silla } \\
\text { River }\end{array}$ & $25^{\circ} 40^{\prime} 15^{\prime \prime}$ & $100^{\circ} 7^{\prime} 43^{\prime \prime}$ & $0.98 \pm 0.02$ & 30.6 & 8.21 & 354 & 722 & 112.8 & 0.1 \\
\hline 5 & $\begin{array}{c}\text { Santa } \\
\text { Catarina } \\
\text { River }\end{array}$ & $25^{\circ} 40^{\prime} 16^{\prime \prime}$ & $100^{\circ} 7^{\prime} 43^{\prime \prime}$ & $0.44 \pm 0.04$ & 32.4 & 8.25 & 350 & 714 & 103.0 & 0.1 \\
\hline 8 & \multirow{3}{*}{$\begin{array}{c}\text { San Juan } \\
\text { River }\end{array}$} & $25^{\circ} 32^{\prime} 12^{\prime \prime}$ & $99^{\circ} 51^{\prime} 17^{\prime \prime}$ & $0.94 \pm 0.02$ & 31.4 & 7.61 & 452 & 922 & 111.0 & 0.2 \\
\hline 9 & & $25^{\circ} 32^{\prime} 34^{\prime \prime}$ & $99^{\circ} 50^{\prime} 04^{\prime \prime}$ & $0.23 \pm 0.07$ & 30.1 & 8.08 & 352 & 718 & 171.7 & 0.1 \\
\hline 10 & & $25^{\circ} 31^{\prime} 40^{\prime \prime}$ & $99^{\circ} 37^{\prime} 19^{\prime \prime}$ & $0.75 \pm 0.02$ & 29.9 & 9.01 & 450 & 917 & 168.5 & 0.2 \\
\hline 11 & $\begin{array}{c}\text { El } \\
\text { Cuchillo }\end{array}$ & $25^{\circ} 43^{\prime} 31^{\prime \prime}$ & $99^{\circ} 19^{\prime} 27^{\prime \prime}$ & $<\mathrm{LOD}^{\mathrm{a}}$ & 30.7 & 8.14 & 302 & 617 & 211.9 & 0.1 \\
\hline
\end{tabular}

Tabla 1: $<\mathrm{LOD}^{\mathrm{a}}$ : below the limit of detection.

2.1.2 Sediments. A $4.4 \mathrm{~cm}$ i.d. by $50 \mathrm{~cm}$ long custom-made sediment core sampler meeting the US EPA specifications [23] was used to collect sediment samples. All samples were placed in polyethylene bags and frozen before being subjected to analysis.

\subsection{Laboratory analysis}

2.2.1 Water samples

Water samples were filtered through Whatman No. 41 filter paper. Filtered samples were acidified at $\mathrm{pH} 2$ with $0.5 \mathrm{~mL}$ of $\mathrm{HNO}_{3}(65 \% \mathrm{w} / \mathrm{v})$ and stored at $4^{\circ} \mathrm{C}$ until analysis. Total $\mathrm{Hg}$ was quantified in water samples during the first week after field sampling.

2.2.2 Sediments

Sediment samples were thawed, brought to room temperature and homogenized. Percent moisture was determined on a separate representative portion of the sample by loss of mass upon heating below $40^{\circ} \mathrm{C}$ to minimize losses of $\mathrm{Hg}$ [2]. Results on a dry weight basis were used to remove some of the variability associated with wet samples. The average moisture content of samples was $27 \pm 6 \%(n=11)$. The dry samples were further grounded and homogenized in agate mortar, and sieved through $63 \mathrm{~m} \mu$ mesh, proceeding to store it in a propylene container.

For total $\mathrm{Hg}$, sediment samples were digested using the EPA Method 3052 [24] microwave-assisted method in closed vessels (CEM MSP-1000 Microwave Sample Preparation System). Approximately, $1 \mathrm{~g}$ representative wet samples were weighed into microwave vessels followed by the addition of $9 \mathrm{~mL}$ concentrated $\mathrm{HNO}_{3}$ and $2 \mathrm{~mL}$ concentrated $\mathrm{HCl}$. Vessels were then sealed and microwave irradiated at $180^{\circ} \mathrm{C}$ for $10 \mathrm{~min}$. Following digestion, the Teflon ${ }^{\circledR}$ PFA (perfluoroalkoxy) microwave vessels were cooled down and the digests diluted to $25 \mathrm{~mL}$ in volumetric flasks with double-deionized (DDI) water $(18 \mathrm{M} \Omega-\mathrm{cm})$ obtained from a Barnstead NANOpure Water System (Dubuque, IA, USA)

\subsubsection{Fractionation procedure}

A three-step sequential extraction procedure was performed as described in US EPA 3200 method $[21,25,26]$. This procedure included a sequential extraction process for different operationally defined fractions (mobile $\mathrm{Hg}$, semi-mobile $\mathrm{Hg}$, and non-mobile $\mathrm{Hg}$ ) and provided detailed information about the mobility of $\mathrm{Hg}$ in all samples. Sequential extraction procedures (SEPs) have been widely used to determine the partitioning of contaminants associated with different categories of soil constituents and to elucidate the transfer potential and thus the availability and mobility according to the extractability by various operationally defined solvents [27]. Extractions were carried out using moist samples weighing $1 \mathrm{~g}$. After completion of the specific conditions of each stage, mixtures were centrifuged at $3300 \mathrm{rpm}$ for $5 \mathrm{~min}$. For each sample, the supernatant was transferred to a volumetric flask, and if necessary acidified with $\mathrm{HNO}_{3}$ at $\mathrm{pH}<2$ and then diluted to $25 \mathrm{~mL}$ before analysis. The residue was then treated following the conditions summarized in Table 2 .

Table 2. Sequence of extracting agents and operationally defined fractions in the sequential extraction procedure $[21,25,26]$.

\begin{tabular}{|c|c|c|c|}
\hline Fraction & $\begin{array}{l}\text { Mercury containing } \\
\text { species }\end{array}$ & $\begin{array}{c}\text { Extracting } \\
\text { agent }\end{array}$ & $\begin{array}{l}\text { Extraction } \\
\text { conditions }\end{array}$ \\
\hline Mobile $\mathrm{Hg}$ & $\begin{array}{l}\text { Alkyl Hg species } \\
(\mathrm{MeHgCl}, \mathrm{EtHgCl}) \\
\text { Soluble inorganic } \\
\mathrm{Hg}\left(\mathrm{HgCl}_{2},\right. \\
\mathrm{Hg}(\mathrm{OH})_{2}, \mathrm{Hg}\left(\mathrm{NO}_{3}\right)_{2}, \\
\mathrm{HgSO}_{4}, \mathrm{HgO}, \mathrm{Hg}^{2+} \\
\left.\text { complexes }^{+}\right)\end{array}$ & $4 \mathrm{M} \mathrm{HNO}_{3}$ & $\begin{array}{l}\text { The sample was } \\
\text { extracted with } 10 \\
\mathrm{~mL} \text { of } 4 \mathrm{M} \mathrm{HNO}_{3} \text { in } \\
\text { a microwave oven at } \\
100^{\circ} \mathrm{C} \text { for } 10 \text { min. A } \\
\text { 3-min ramping time } \\
\text { was used to reach } \\
\text { the temperature of } \\
100^{\circ} \mathrm{C} \text {. The residue } \\
\text { of this step was } \\
\text { washed with DDI } \\
\text { water }\end{array}$ \\
\hline $\begin{array}{l}\text { Semi- } \\
\text { mobile Hg }\end{array}$ & $\begin{array}{l}\mathrm{Hg} \text { or } \mathrm{Hg}-\mathrm{M}^{\mathrm{b}} \\
\mathrm{Hg}^{2+} \text { complexes } \\
\mathrm{Hg}_{2} \mathrm{Cl}_{2} \text { (minor) }\end{array}$ & $\begin{array}{l}1: 2 \mathrm{HNO}_{3}: \\
\text { DDI water }\end{array}$ & $\begin{array}{l}\text { The residue from } \\
\text { the previous step } \\
\text { was extracted twice } \\
\text { with } 10 \mathrm{~mL} \text { of } 1: 2 \\
\mathrm{HNO}_{3}: \text { DDI water in } \\
\text { a water bath heated } \\
\text { at } 95 \pm 2{ }^{\circ} \mathrm{C} \text { for } 20 \\
\text { min. The residue } \\
\text { of this step was } \\
\text { washed with DDI } \\
\text { water }\end{array}$ \\
\hline $\begin{array}{l}\text { Non- } \\
\text { mobile } \mathrm{Hg}\end{array}$ & $\begin{array}{l}\mathrm{Hg}_{2} \mathrm{Cl}_{2} \text { (major) } \\
\mathrm{HgS} \\
\mathrm{HgSe}\end{array}$ & $\begin{array}{l}\text { 1:6:7 HCl: } \\
\mathrm{HNO}_{3} \text { : } \\
\text { DDI water }\end{array}$ & $\begin{array}{l}\text { The residue from } \\
\text { the previous step } \\
\text { was extracted twice } \\
\text { with } 10 \mathrm{~mL} \text { of } 1: 6: 7 \\
\mathrm{HCl}: \mathrm{HNO}_{3}: \text { DDI } \\
\text { water in a water } \\
\text { bath heated at } 95 \pm 2 \\
{ }^{\circ} \mathrm{C} \text { for } 20 \text { min. }\end{array}$ \\
\hline
\end{tabular}

${ }^{\mathrm{a}}$ Certain inorganic mercury complexes may be present in both fractions.

${ }^{\text {b}}$ This represents a mercury-metal amalgam 


\subsubsection{Analytical procedure for total $\mathrm{Hg}$ determination}

The determination of the total $\mathrm{Hg}$ in water samples, and acid digests and extracts of sediment samples were performed by cold vapor atomic absorption spectrophotometry (CVAAS) in a Varian SpectrAA5 apparatus equipped with a continuous flow VGA-77 Vapor Generation Accessory. Total Hg concentrations were determined using the conventional CVAAS procedure following the reduction of inorganic $\mathrm{Hg}$ with $\mathrm{SnCl}_{2}$ in acidic medium [28]. Quantification of mercury was based on aqueous standard calibration curves (external calibration). The $\mathrm{Hg}$ concentration was within the range $1-10 \mu \mathrm{g} / \mathrm{L}$. The limit of detection (LOD) for water and sediment samples were $0.21 \mu \mathrm{g} / \mathrm{L}$ and $0.021 \mathrm{mg} / \mathrm{Kg}$, respectively. The LOD was defined as three times the standard deviation of three measurements of the blank, divided by the slope of the calibration curve. Water samples were analyzed in duplicate and sediment samples were analyzed in triplicate. Blank samples and certified reference material for marine sediment IAEA-433 acquired from the International Atomic Energy Agency (Geneva, Switzerland) with a total $\mathrm{Hg}$ concentration of $0.168 \pm 0.017 \mathrm{mg} / \mathrm{Kg}$ were routinely analyzed with each batch of samples to evaluate the accuracy and precision of the analytical procedure. Certified and measured values were in agreement with a recovery efficiency of $98 \pm$ $13 \%$. For the analysis of water samples, the proposed method was validated by spiking the sample with known amount of inorganic mercury. The recoveries from spiked solutions were varied in the range $92-97 \%$.

2.2.5 Other physical and chemical parameters

Water quality parameters, including $\mathrm{pH}$, redox potential, temperature, conductivity, dissolved oxygen (DO), total dissolved solids (TDS), and salinity were simultaneously measured in the field. An Orion $290 \mathrm{~A} \mathrm{pH}$ meter was used for $\mathrm{pH}$ and redox potential $\left(\mathrm{E}_{\mathrm{h}}\right)$ measurements; $\mathrm{DO}$ was measured using an Orion 835 Dissolved Oxygen meter; and temperature, conductivity and TDS were measured with an Orion 135 probe.

2.2.6 Statistical methods

Pearson's correlation was used to evaluate the associations between parameters. All statistical analyses were performed with SPSS software version 17 (SPSS Inc., Chicago, IL, USA). A two-tailed $\mathrm{p}<0.05$ was considered statistically significant.

\section{RESULTS AND DISCUSSION}

Eleven representative sampling points of varying degree of pollution of the San Juan River Watershed were selected on the basis of previous reports in this area $[19,20]$ and unpublished work from our laboratory.

\subsection{Water quality}

Sampling locations with coordinates and environmental conditions during sampling with total $\mathrm{Hg}$ concentration found in filtered river samples are shown in Table 1. Water samples from San Juan River watershed recorded temperatures ranging $24.0-34.5^{\circ} \mathrm{C}$. Standards for temperature to sustain aquatic life establish a range between $20-30^{\circ} \mathrm{C}$. The $\mathrm{pH}$ is the indicator of acidic or alkaline conditions of waterbodies. The standard for any purpose in-terms of $\mathrm{pH}$ is 6.5-8.5 [29]; in this regard, the $\mathrm{pH}$ of San Juan River ranged from 7.60 to 9.01 with a mean value of 8.3 indicating alkaline water streams. Total dissolved solids (TDS) ranged from $252 \mathrm{mg} / \mathrm{L}$ at sample site 2 to $452 \mathrm{mg} / \mathrm{L}$ at sample site 8 . Although, TDS is a non-priority pollutant in surface waters, but the EPA suggests a maximum level of $250 \mathrm{mg} / \mathrm{L}$ to minimize harm to humans and aquatic life [30]. The average electrical conductivity was $720 \mu \mathrm{S} / \mathrm{cm}$. This high value observed at the San Juan River watershed could be related to the high level of TDS in this waterbody. The mean $\mathrm{E}_{\mathrm{h}}$ was $134.5 \mathrm{mV}$, which ranged from 85.10 to $211.90 \mathrm{mV}$, while the average salinity was $1.2 \mathrm{mg} / \mathrm{L}$.

Some of the physicochemical parameters such as $\mathrm{pH}$, temperature and TDS exceed the water quality standards. These results could be indicative of contamination problems in the San Juan River watershed and were in agreement with a preliminary study carried out by Flores-Laureano and Navar [20].

Horvart et al. [7] pointed out that total $\mathrm{Hg}$ concentration in water streams could be affected by the hydrological conditions prevalent the sampling period. In this study, total $\mathrm{Hg}$ concentrations in water samples were variable across the region (Table 1) and ranged from 0.17 to $1.14 \mu \mathrm{g} / \mathrm{L}$ with a mean value of $0.63 \mu \mathrm{g} / \mathrm{L}$. The tributary Santa Catarina River, sampling point 3 showed the highest concentration of total $\mathrm{Hg}$, which was below the maximum concentration level of $\mathrm{Hg}(10 \mu \mathrm{g} / \mathrm{L})$ set by the environmental regulations for wastewater effluents in Mexico [31]. The Santa Catarina River originates from the hills of Sierra La Huasteca and flows to the San Juan River in the State of Nuevo Leon, passing through the counties of Santa Catarina, San Pedro Garza Garcia, Guadalupe, Escobedo, Juarez and Cadereyta as well as the urban area of Monterrey. The high concentration observed in the river water could be related to anthropogenic wastewater releases by local residents and industry. The lowest $\mathrm{Hg}$ concentration in water samples was found in the Cuchillo reservoir (sampling point 11). This reservoir supplies domestic and industrial water to the MAM. In general terms, the average concentration of total $\mathrm{Hg}$ in the San Juan River watershed was not higher than the US EPA ambient surface water quality criteria $(0.77-1.4 \mu \mathrm{g} / \mathrm{L})$ [30]. Furthermore, some of the sampling sites evaluated in this study, including sampling points 5, 6, 9, and 11, were below $0.5 \mu \mathrm{g} / \mathrm{L}$, which is the World Health Organization (WHO) guideline value for $\mathrm{Hg}$ in groundwater and surface waterbodies [32]. Sampling site 6 was located downstream La Silla River tributary and could contribute to dilute some of the contamination of the main stream of the San Juan River. Sampling site 6 was located downstream one of the three wastewater treatment plants established in 1994 by the government of the Estate of Nuevo Leon through the metropolitan area program "Monterrey Plan IV". The objective of this program was to eradicate pollution problems in the San Juan River watershed [20].

\subsection{Sediment samples}

Total $\mathrm{Hg}$ concentrations in sediment samples following acid digestion are shown in Table 3. Concentrations were expressed on a dry weight basis. The concentration of total $\mathrm{Hg}$ in sediments was fairly uniform across the study area. Total $\mathrm{Hg}$ concentrations ranged from 0.289 to $0.501 \mathrm{mg} / \mathrm{Kg}$ with a mean value of $0.405 \pm 0.074 \mathrm{mg} / \mathrm{Kg}$. As compared with other waterbodies, $\mathrm{Hg}$ concentrations in the San Juan River watershed sediment samples were higher than the concentrations of $\mathrm{Hg}$ reported in the Coatzacoalcos estuary $(0.07-1.06 \mathrm{mg} / \mathrm{Kg})$ [14]. However, a lower level of $\mathrm{Hg}$ in sediment samples was reported in the Papaloapan River Basin located in southern Veracruz, Mexico (0.027-0.090 mg/Kg) [12]. The lowest and highest content of total $\mathrm{Hg}$ in sediment samples were observed in the Santa Catarina River sampling site 1 and 2, respectively. However, the higher levels found at sampling site 2 were not surprising because this site was located in the immediate vicinity of the MAM. Hg accumulation in sediment from sampling site 2 could be attributed to industrial activities in this area. Despite of $\mathrm{Hg}$ accumulation nearby the MAM, Hg levels were within range for values reported for uncontaminated sediment samples $(0.2-0.4 \mathrm{mg} / \mathrm{Kg})$ [33]. In addition, the average concentration of $\mathrm{Hg}$ in sediment samples taken from this study area was below the maximum concentration criteria levels proposed by the US EPA for unpolluted sediments $(<1 \mathrm{mg} / \mathrm{Kg})[34]$. These results suggest that local sediments have not yet been impacted severely by $\mathrm{Hg}$ contamination. By adopting the National Oceanic and Atmospheric Administration (NOAA's) screening reference guideline [35], the average $\mathrm{Hg}$ concentration in sediment samples from this study was in the category of moderately polluted sediments $(0.15-1.30 \mathrm{mg} / \mathrm{Kg})$. Although sediment quality criteria for $\mathrm{Hg}$ have been set in some countries [33, 35], it is necessary to evaluate the reactivity, solubility and potential bioavailability of $\mathrm{Hg}$ in sediments [36] (Table 2). The levels of $\mathrm{Hg}$ extracted from sediment samples can be seen in Fig. 2. The distribution of $\mathrm{Hg}$ in the fractions was similar across the sampling site locations. Results showed that $\mathrm{Hg}$ was mainly distributed in the non-mobile $\mathrm{Hg}$ fraction $(0.29 \pm 0.07 \mathrm{mg} / \mathrm{Kg})$, which accounted for $71 \pm 10 \%$ of total $\mathrm{Hg}$ in sediments. The non-mobile fraction is related to elemental and strongly bound $\mathrm{Hg}$ compounds. The semi-mobile fraction of $\mathrm{Hg}$ represented nearly $9 \%$ of the total $\mathrm{Hg}(0.038 \mathrm{mg} / \mathrm{Kg})$, whereas the mobile fraction represented $20 \pm 8 \%$ of total $\mathrm{Hg}$. The mobile fraction contains most of the available fraction of $\mathrm{Hg}$, including methylmercury $(\mathrm{MeHg})$, thus making it the most toxic fraction. Total $\mathrm{Hg}$ content in this fraction corresponded to $0.079 \pm 0.028 \mathrm{mg} / \mathrm{Kg}$ of total $\mathrm{Hg}$ in sediments samples.

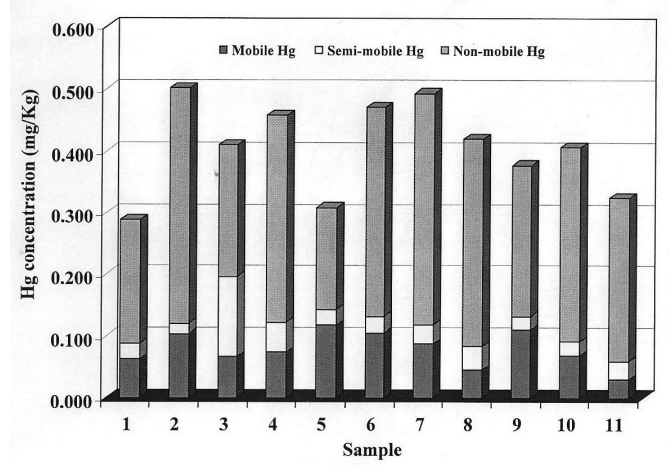

Fig. 2. Sequential chemical fractionation of $\mathrm{Hg}$ in sediment samples from San Juan River watershed. 
Table 3. Mercury content in the sediment samples from San River watershed.

\begin{tabular}{|c|c|c|}
\hline \multirow{2}{*}{ Sample } & Site & $\begin{array}{c}\text { Mercury content } \\
\text { (mg/Kg dry weight })^{\boldsymbol{a}}\end{array}$ \\
\hline 1 & Santa Catarina River & $0.297 \pm 0.008$ \\
\hline 2 & & $0.533 \pm 0.004$ \\
\hline 3 & & $0.410 \pm 0.006$ \\
\hline 4 & La Silla River & $0.459 \pm 0.005$ \\
\hline 5 & Santa Catarina River & $0.313 \pm 0.007$ \\
\hline 6 & & $0.470 \pm 0.005$ \\
\hline 7 & & $0.495 \pm 0.010$ \\
\hline 8 & & $0.450 \pm 0.011$ \\
\hline 9 & & $0.317 \pm 0.016$ \\
\hline 10 & & $0.408 \pm 0.012$ \\
\hline 11 & San Juan River & $0.300 \pm 0.017$ \\
\hline
\end{tabular}

${ }^{a}$ The values are means $\pm 95 \%$ confidence level $(n=3)$.

3.3 Association between $\mathrm{Hg}$ and environmental parameters in the San Juan River watershed.

In this study, associations between $\mathrm{Hg}$ concentrations and several environmental factors were estimated using the Pearson's correlation coefficient $(\mathrm{r})$. Correlation tests having P-values $<0.05$ indicated strong association between tested variables. The statistical analysis revealed a highly significant positive correlation $(\mathrm{p}<0.01)$ between total $\mathrm{Hg}$ in sediments and the non- mobile $\mathrm{Hg}$ fraction $(\mathrm{r}=0.862)$.

There was a strong positive correlation $(\mathrm{p}<0.05)$ between total $\mathrm{Hg}$ levels in water samples and the semi-mobile $\mathrm{Hg}$ fraction in sediments $(\mathrm{r}=0.650)$. Pearson correlation analysis indicated that total $\mathrm{Hg}$ concentrations in water samples were negatively correlated with the redox potential measured in the samples $(\mathrm{r}=-0.660, \mathrm{p}<0.05)$. However, Pearson's correlation analysis indicated that $\mathrm{Hg}$ levels in water samples were not associated with $\mathrm{pH}(\mathrm{r}=0.195, \mathrm{p}>0.05)$. The concentration of total $\mathrm{Hg}$ and $\mathrm{MeHg}$ in aquatic environment can be influenced by several physical and chemical parameters including temperature, $\mathrm{pH}$, salinity, organic carbon, redox potential, bacterial activity, inorganic and organic complexing agents and organic matter content [37,38]. Alkaline $\mathrm{pH}$ waters and total $\mathrm{Hg}$ average concentrations below the US EPA ambient surface water quality criteria [30] were observed within the San Juan River Watershed. The weak correlation between $\mathrm{Hg}$ content and some physicochemical variables could indicate the influence of the local anthropogenic activities [39].

\section{CONCLUSIONS}

The San Juan River watershed was characterized by relatively low levels of $\mathrm{Hg}$. The slightly higher $\mathrm{Hg}$ concentrations found at some monitoring points could be related to diffuse sources of $\mathrm{Hg}$, such as anthropogenic and industrial activities. Concentrations of $\mathrm{Hg}$ in water samples varied from 0.17 to 1.14 $\mu \mathrm{g} / \mathrm{L}$ and were below the maximum concentration for $\mathrm{Hg}$ established by the mexican environmental regulations. Additionally some of the physiochemical parameters such as $\mathrm{pH}$, TDS and temperature exceeded the drinking water safety levels. On the other hand, $\mathrm{Hg}$ concentrations in surface sediments were very similar among all the sampling sites and ranged from 0.289 to $0.501 \mathrm{mg} /$ $\mathrm{Kg}$. A significant amount of $\mathrm{Hg}$ in sediments was found to be associated with the non-mobile fraction that corresponds to a number of very stable chemical species with low mobility.

The study was conducted to help assess the need for a more comprehensive survey of $\mathrm{Hg}$ distribution in this ecosystem, which may eventually have an impact on the health of the nearly four-million inhabitant metropolitan area of Monterrey, known to harbor the largest metallurgical urban zone in northern Mexico.

\section{ACKNOWLEDGEMENTS}

Financial support from Chemistry School of the Universidad Autonoma de Nuevo Leon is gratefully acknowledged. The authors thank IAEA for kindly providing the reference material. Also, thanks are given to Ing. Pedro Garza Treviño, Managing Director of CNA in Nuevo Leon, for his assistance in the field sampling. Laura H. Reyes acknowledges to Conacyt the financial support (grant 116627) through the Repatriation Program 2009.

\section{REFERENCES}

1 US EPA, Mercury Study Report to the Congress. In: Office of Air Quality Planning and Standards and Office of Research and Development: Washington, DC, USA, (1997).

2 T. Stoichev, D. Amouroux, R.C. Rodriguez Martin-Doimeadios, M. Monperrus, O.F.X. Donard, D.L. Tsalev, Appl. Spectrosc. Rev., 41, 591, (2006).

3 P. B. Tchounwou, W. K. Ayensu, , N. Ninashvili, D. Sutton, Environ. Technol., 18, 149, (2003).

4 N. M. Lawson, R.P. Mason, Water Res., 35, 4039, (2001)

5 J. L. Marrugo-Negrete, N. Benitez, J. Olivero-Verbel, Arch. Environ. Contam. Toxicol., 55, 305, (2008).

6 J. E.Creswell, S. C.Kerr, , M. H. Meyer, C. L. Babiarz, M. M. Shafer, D. E. Armstrong, E. E. Roden, J. Geophys. Res.-Biogeo., 113, CiteID G00C02, (2008).

7 M. Horvat, N. Nolde, V. Fajon, V. Jereb, M. Logar, S. Lojen, R. Jacimovic, I. Falnoga, Q. Liya, J. Faganeli, D. Drobne, Sci. Total Environ., 304, 231, (2003).

8 J. Narvaez, P. Richer, M. I. Toral, J. Chil. Chem. Soc., 52, 1261, (2007).

9 V. Herrera, I. De Gregori, H. Pinochet, J. Chil. Chem. Soc., 54, 282, (2009).

10 N. Ogrinc, M. Monperrus, J. Kotnik, V. Fajon, K. Vidimova, D. Amouroux, D. Kocman, E. Tessier, S. Zizek, M. Horvat, Mar. Chem., 107, 31, (2007).

11 B. Wyrzykowska, J. Falandysz, J. Phys. IV, 107, 1381, (2003).

12 J. L. Guentzel, E. Portilla, K. M. Keith, E. O. Keith, Sci. Total Environ., $388,316,(2007)$.

13 E. Gutiérrez-Galindo, D. Casas-Beltrán, A. Muñoz-Barbosa, L. Daesslé, J. Segovia-Zavala, J. Macías-Zamora, M. Orozco-Borbón, Environ. Contam. Tox., $80,123,(2008)$

14 J. Ruelas-Inzunza, F. Paez-Osuna, N. Zamora-Arellano, F. AmezcuaMartinez, H. Bojorquez-Leyva, Water Air. Soil. Pollut., 197, 165, (2009).

15 A. Maqueda Estrada, Assessment of land cover change effect on the San Juan River watershed hydrology in Nuevo Leon, Mexico, MS Dissertation, Texas A\&M University Kingsville, Kingsville TX, USA, (2007).

16 J.Navar, Geofis. Inter., 40,121, (2001).

17 J.Navar, Geofis. Inter., 43, 495, (2004)

18 INEGI XII censo de población y vivienda. Instituto Nacional de Estadística Geografía e Informática. http://www.inegi.gob.mx. Accessed 25 June 2009, (2006).

19 U.Kramar, C. J. Barbarın, H. Puchelt, H.W. Hubberten, F. Viera, Zentralbl. Geol. Paläontol., 6, 1917, (1992).

20 J. S. Flores Laureano, J.Navar, J. Environ. Qual., 31,1256, (2002).

21 US EPA, Method 3200: Mercury Species Separation by Selective Solvent Extraction and Acid Digestion, US Government Printing Office (GPO), Washington, DC, USA, (2004)

22 Ministry of Urban Development and Ecology of Nuevo Leon Programa Estatal de Ordenamiento Territorial de Nuevo León. Fases I y II. Secretaría de Desarrollo Urbano y Obras Públicas. Subsecretaría de Ecología. Planificación Urbana, Regional y Ecológica, (2003).

23 US EPA, Methods for Collection, Storage and Manipulation of Sediments for Chemical and Toxicological Analyses: Technical Manual. EPA 823B-01-002. U.S. Environmental Protection Agency, Office of Water, Washington, DC. USA, (2001).

24 US EPA,Method 3052: Microwave assisted acid digestion of siliceous and organically based matrices. In: Test Methods for evaluating solid waste, physical/chemical methods SW-846. US Government Printing Office (GPO), Washington, DC, USA, (1996).

25 Y.Han, H.M. Kingston, H. M. Boylan, G.M. Rahman, S. Shah, R.C. Richter, D. C. Link, S. Bhandari, Anal. Bioanal. Chem., 375, 428, (2003).

26 G. M. M.Rahman, H. M. S. Kingston, Development of MicrowaveAssisted Extraction Method and Isotopic Validation of Mercury Species in Soils and Sediments. J. Anal. At. Spectrom., 20, 183, (2005).

27 N. Issaro, C. Abi-Ghanem, A. Bermond, Anal. Chim. Acta, 631, 1, (2009).

28 L. M. Beach, Evaluation of the Mercury Concentration Accessory for US EPA Methodology. Varian Instruments at Work. No. AA-108, 1992, pp. $1-5$.

$29 \mathrm{WHO}, \mathrm{pH}$ in drinking water. Background document for preparation of WHO guidelines for drinking-water quality. World Health Organization, Genova, (2003). 
30 US EPA, National recommended water quality criteria. US Environmental Protection Agency. http://epa.gov/waterscience/criteria/wqctable/ nrwqc-2006.pdf. Accessed 25 June 2009. (2006).

31 NOM-001-SEMARNAT-1996 (Norma Oficial Mexicana). Límites máximos permisibles de contaminantes en las descargas de aguas residuales en aguas y bienes nacionales. Diario Oficial de la Federación, 23 de Abril del 2003.

32 WHO Mercury in drinking-water. Background document for development of WHO Guidelines for drinking-water quality. World Health Organization, Geneva, (2005)

33 P. K. Rai, Hum. Ecol. Risk Assess., 14, 1318, (2008).

34 N. G. Bigham, A. E. Henry, Mercury in sediments - How clean is clean? In: Mercury and Arsenic Wastes. Pollution Technology Review No. 214 U.S. Environmental Protection Agency, p. 11, (1993).
35 M. F. Buchman, NOAA Screening Quick Reference Tables, NOAA HAZMAT Report 99-1, Seatle WA. Coastal Protection and Restoration Division, National Oceanic and Atmospheric Administration, p. 12. (1999).

36 S. M. Ullrich, T. W. Tanton, S. A. Abdrashitova, Crit. Rev. Env. Sci. Technol., 31, 241, (2001).

37 M. Ravichandran, Chemosphere, 55, 319, (2004).

38 R. P. Mason, J. M. Benoit, Organomercury compounds in the environment. In: Organometallic compounds in the environment, Edited by PJ Craig $(\mathcal{C}$ John Wiley and Sons, 2003; pp. 57-99.

39 C. M. Valle, G. P.Santana, R. Augusti, F. B. Egreja Filho, C. C. Windmoller, Chemosphere, 58, 779, (2005). 